\title{
Status of the major lobster fisheries in India
}

\author{
E. V. RADHAKRISHNAN \\ V. D. DESHMUKH \\ MARY K. MANISSERI \\ M. RAJAMANI \\ JOE K. KIZHAKUDAN

\section{R. THANGARAJA}

Central Marine Fisheries Research Instilute

Cochin 682018

Kerala, India

email: mdcmfri@md2.vsnl.net.in

\begin{abstract}
Commercial exploitation of lobsters from the Indian seas began in the 1950s. Annual landings have been declining from a peak of $4075 \mathrm{t}$ in 1985 to $1364 \mathrm{t}$ in 2002. Major fisheries were located on the north-west, south-west, and south-east coasts. Among the 12 species recorded, only four species of spiny lobsters (three littoral and one deep sea) and one species of slipper lobster are commercially important. At Kayalpattinam and Tharuvaikulam, on the south-east coast, lobster landings sharply declined for the gill-net fishery. Of the two species that contributed to the fishery, Panulirus ornatus and Panulirus homarus, the latter has been more affected owing to high vulnerability to fishing activities. Catch composition analysis of the trammel-net fishery showed that $35 \%$ of the landings consisted of $P$. homarus in the size range of 23$50 \mathrm{~mm}$ carapace length. On the north-west coast, the spiny lobster Panulirus polyphagus and the slipper lobster Thenus orientalis are incidentally caught in trawl nets. However, the fishery for $T$. orientalis in the waters off Mumbai lasted only up to 1994. Largescale exploitation of spawning females, which
\end{abstract}

M04014; Online publication date 8 June 2005 Received 8 February 2004; accepred 18 April 2005 formed $60 \%$ of the total catch, might have been detrimental to the recruitment process resulting in rapid decline and total collapse of the fishery. Abundance of $P$. polyphagus reached its maximum during September, constituting $23 \%$ of the average annual landing during 1988-2002. A high exploitation ratio $(>0.7)$ indicated over-fishing of the stock. Repeated spawning and high annual egg production are probably responsible for sustaining the stock, despite over-exploitation. Major problems confronting the resource management of the multi-gear and multispecies lobster fisheries in India are discussed. An operational project, involving fisher community, has been taken up for creating awareness of the need for sustainable exploitation of the resource. Regulatory measures, such as closure of the fishery during the peak of the breeding season, ban on trammel-net, mandatory release of egg-bearing lobsters, and establishment of lobster sanctuaries are suggested to the State Governments for implementation.

Keywords lobster fishery; stock assessment; overexploitation; management

\section{INTRODUCTION}

Lobsters are one of the most valuable and highly priced crustaceans in India, as well as an important export commodity. Though widely distributed along the entire coast, major fisheries are located on the north-west, south-west, and south-east coasts (Radhakrishnan \& Manisseri 2003). The north-west coast is particularly rich in lobster resources, contributing to nearly three quarters of the total lobster landing in India (Kagwade et al. 1991; Radhakrishnan 1995). Two species, the palinurid spiny lobster Pamulirus polyphagus (Herbst) and scyllarid Thenus orientalis (Lund) predominate in the fishery along the north-west coast (Chhapgar \& Deshmukh 1971). At Mumbai and Veraval, in the north-west, lobsters are incidentally caught in trawl nets. Extensive information is available on the reproductive biology and growth of $P$. polyphagus 


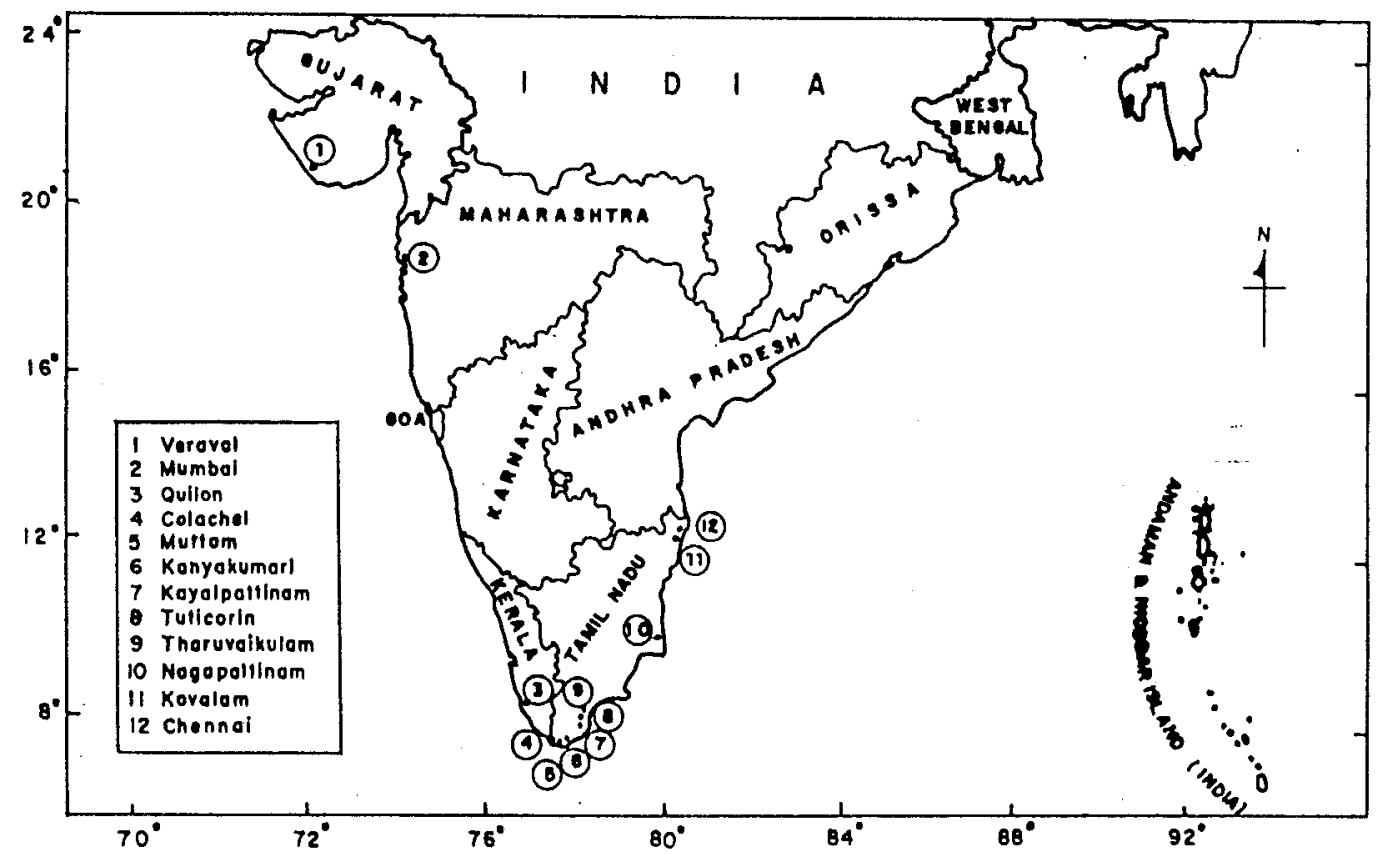

Fig. 1 Major lobster fishing centres along the Indian coast.

(Kagwade 1987a,b, 1988a,b) and T. orientalis (Kabli \& Kagwade 1996a,b,c). As a result of the absence of regulatory measures for the fishery in the State of Maharashtra, the sand lobster fishery collapsed by 1994 and there is no sign of its recovery (Deshmukh 2001).

In the south-west, Panulirus homarus (Linnaeus) and the deep sea lobster, Puerulus sewelli (Ramadan), are the top contributors to the fishery. However, Panulirus versicolor Latreille and Panulirus ornatus (Fabricius), are also landed in small quantities. Colachel and Muttom are the major fishing grounds, where gill-net, trammel-net, and traps are used for catching lobsters. The fishery and biology of $P$. homarus were studied during the 1950s and 1960s (Miyamoto \& Sheriff 1961; Balasubramaniam et al. 1960, 1961; George 1965). Mohammed \& George (1968) conducted tagging experiments at Muttom to study the movement and growth of $P$. homarus. Major fishing grounds for the deep sea lobster, $P$. sewelli were located off Quilon in the south-west and off Tuticorin in the south-east coasts, at depths ranging from $150 \mathrm{~m}$ to $400 \mathrm{~m}$. The commercial importance of the resource was established through exploratory surveys (John \& Kurian 1959; Kurian 1964; Silas 1969).
Along the south-east coast, $P$. homarus, $P$. ornatus, and $T$. orientalis were the major species exploited. Linuparus somniosus was reported from the Andaman and Nicobar Islands, but has not been commercially exploited. Kayalpattinam and Tharuvaikulam are important gill-net fishing centres, landing mainly $P$. ornatus and $P$. homarus (Nair et al. 1973; Rajamani \& Manickaraja 1991, 1995 , $1997 a, b)$. Further north, lobsters are mainly caught off Chennai and nearby fishing villages. $T$. orientalis and small quantities of spiny lobsters are landed as bycatch by trawlers at Chennai.

The present work is an altempt to review the general status of the lobster fishery in India. An assessment of the exploited stock of spiny lobster from Mumbai waters during 1998-2002 has also been carried out, which would enable formulation of a management plan for using the lobster resources on a sustainable basis. The "Minimum Legal Size Law" (promulgated in 2003 by the Ministry of Commerce and Industry, Government of India) prohibiting export of lobsters below a certain size, and an educational programme taken up for creating awareness among fishers of the adverse effects of large-scale exploitation of egg-bearing lobsters and juveniles, are also discussed. 


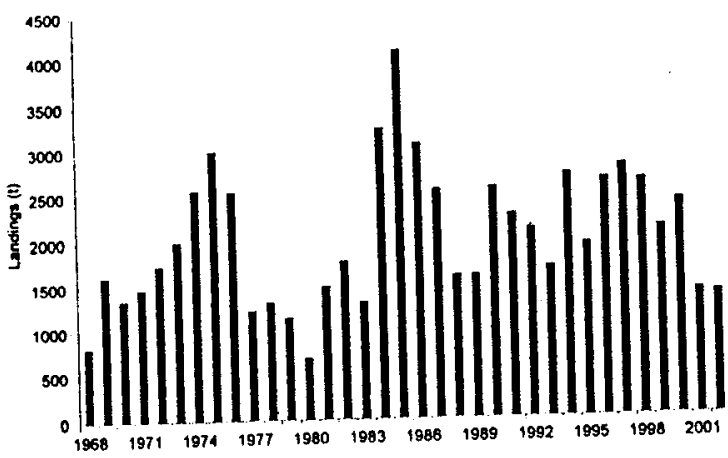

Fig. 2 Total annual lobster landing $(t)$ in India, during 1968-2002.

\section{MATERIALS AND METHODS}

Data on the total landing of lobsters by mechanised trawlers were collected based on a multistage stratified random sampling design. Month-wise catch, fishing effort, and species composition of lobsters caught by the artisanal fishery were estimated by collecting data from major landing centres (Fig. 1). At the landing centres, sex-wise total length (Mumbai) and carapace length (CL) (other centres) were measured by examining 100 specimens each from random samples, once a week. The stock parameters and exploitation rates of the lobster fishery from Mumbai waters were sludied in detail. During 1998-2002, a total of 12727 specimens, comprising 4974 males and 7753 females, were examined at the two trawl landing centres (Sassoon dock and New Ferry Wharf, in Mumbai) for size, sex, and ovigerous condition of females. For $T$. orientalis total length (TL) was measured from the notch in front of the carapace to the posterior margin of the telson. In spiny lobster, it was from the transverse ridge between the supraorbital horns to the tip of telson. CL was measured from the transverse ridge between the supraorbital horns in front, to the posterior margin of the carapace. The lengths were grouped into $10 \mathrm{~mm}$ size classes and sex-wise size frequencies were obtained from each sample. With the help of sex-wise length-weight relationships (Kagwade 1987a; Kabli \& Kagwade 1996c), sample weights were calculated for both sexes in the two species mentioned and a factor was obtained to raise the length-frequencies to the day's catch. The same procedure was followed for raising the lengthfrequencies to the monthly estimated catch after pooling the data for observation days. The monthly length-frequencies were then pooled on an annual basis.

Growth parameters for spiny lobster (Kagwade 1987b) were used to find the exploitation rates during 1998-2002. The natural mortality coefficient was estimated by using Pauly's empirical formula (Pauly 1980) and total mortality coefficient (Z) by length converted catch curve method (Pauly 1984). The exploitation ratio (E) that gave maximum relative yield per recruit $\left(E_{\max }\right)$ and the exploitation $\left(E_{0.50}\right)$ at which the relative biomass per recruit of the stock was reduced to $50 \%$ level, were calculated by using FISAT program (Gayanilo et al. 1996).

\section{RESULTS}

The annual lobster landing increased from $800 \mathrm{t}$ in 1968 to $3000 \mathrm{t}$ in 1975, and attained a peak of 4075 $t$ in 1985 (Fig. 2). Thereafter, the fishery showed a trend of decline, averaging 2200 t for nearly 15 years. The landings further declined to 1389 and $1364 t$ in 2001 and 2002 , respectively. The north-west region contributed $70 \%$, the south-east $16 \%$, and the southwest $14 \%$ of the total landing during 1992-2001.

\section{North-west coast fishery}

At Veraval, the annual landing of lobsters decreased from $315 t$ in 1987 to $102 t$ in 2000 , and then sharply declined to $22 \mathrm{t}$ in 2002 (Fig. 3). During 1987, 189 $t$ of $P$. polyphagus were landed. However, the landing decreased to just 3.9 t during 2002. A similar trend was observed for $T$. orientalis (Fig. 3). The annual mean CL of $P$. polyphagus decreased from $68.5 \mathrm{~mm}$ in males and $74.9 \mathrm{~mm}$ in females in 1997 , to $41.5 \mathrm{~mm}$ and $47.9 \mathrm{~mm}$ respectively, in 2001 . Adults and spawners mainly comprised the trawl catch, whereas gill-net and other traditional gears brought more juveniles. Gill-nets were operated on the shallow reefs, which were inhabited by juveniles and subadults. Peak landing of $P$. polyphagus by trawl nets coincided with the breeding season and the onset of winter in October-December. Maximum landing by gill-nets was during September-October. $T$. orientalis is exploited mostly by multi-day fishing vessels. The mean $\mathrm{CL}$ of this species did not show much variation.

Year-wise landing of lobsters at Mumbai during 1978-2002 is shown in Fig. 4. The annual landings increased from $200 \mathrm{t}$ in 1978, reaching a peak of $1040 t$ in 1986 and thereafter declining to $104 t$ in 2002. Commercial fishery for $T$. orientalis was initiated in 1978, with a catch of $1.5 \mathrm{t}$. The landing 

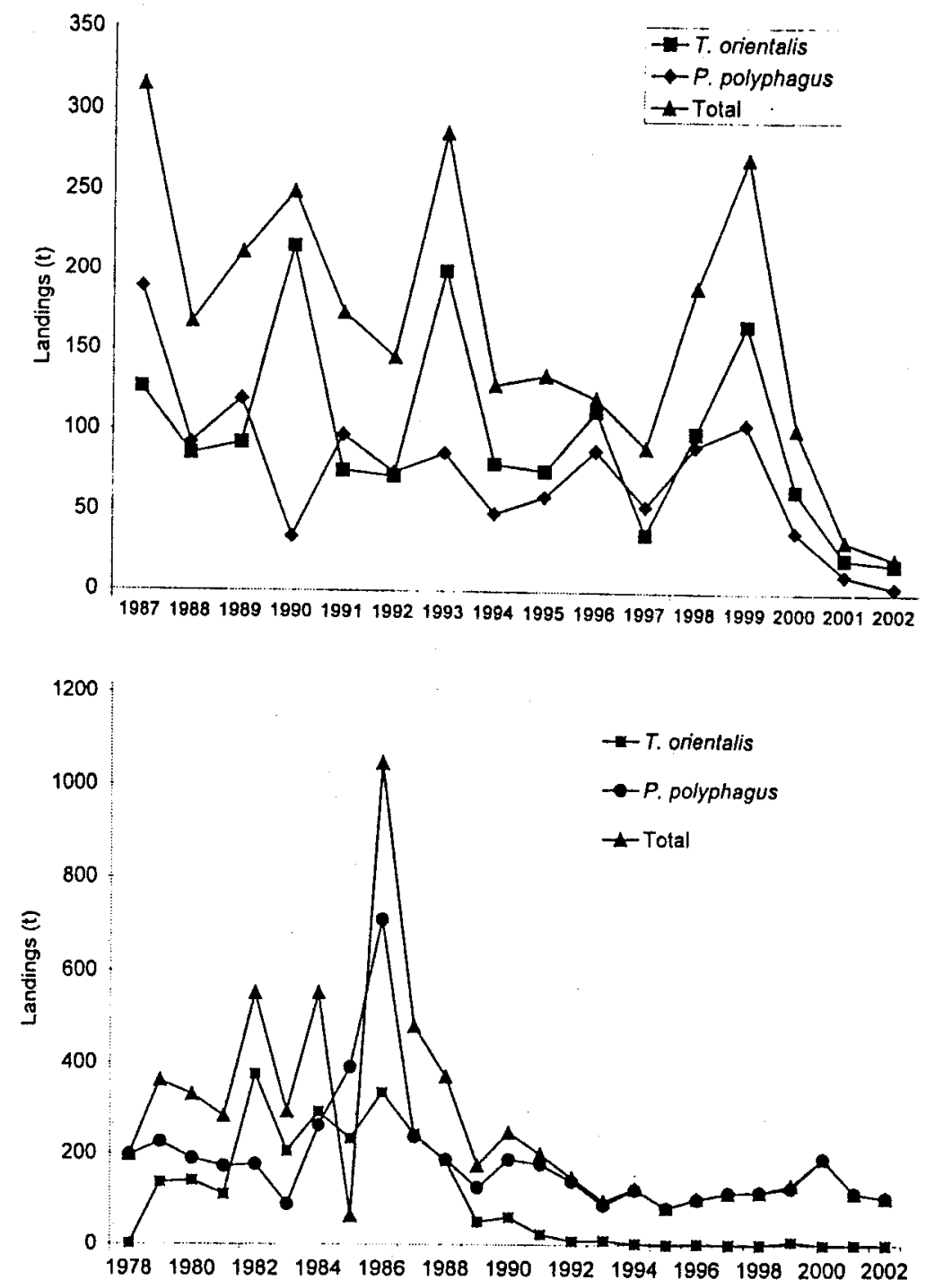

Fig. 3 Annual landing of lobsters (Panulirus polyphagus and Thenus orientalis) in trawl fishery at Veraval, India.

Fig. 4 Annual landing of lobsters (Panulirus polyphagus and Thenus orientalis) in trawl fishery at Mumbai, India. reached a maximum of $375 \mathrm{t}$ in 1982 . Subsequently the catch declined to $250 \mathrm{t}$ and reached another peak $(334 t)$ in 1986 . Thereafter the catch declined rapidly, landing only $2.2 t$ in 1994. As a consequence, the fishery collapsed, and the species occurred only in small quantities in the following years.

The spiny lobster $P$. polyphagus, also showed a gradual decline in landing at Mumbai. The average annual landing during $1978-85$ was $217.5 \mathrm{t}$. However, the catch declined from $390 \mathrm{t}$ in 1985 to $104 \mathrm{t}$ in 2002 (Fig. 4). Month-wise percentage of catches during 1998-2002 showed that the maximum abundance of $P$. polyphagus was in September and the minimum in July. The size of both males and females ranged from $75 \mathrm{~mm}$ to $385 \mathrm{~mm} \mathrm{TL}$, the size between $160 \mathrm{~mm}$ and $230 \mathrm{~mm}$ forming the mainstay of the fishery. The sex ratio showed dominance of females in all years (1:1.16). Ovigerous females occurred throughout the year $(23.8 \%)$ with the peak occurrence $(56.1 \%)$ in September. Recruitment of juveniles, ranging from $70 \mathrm{~mm}$ to $120 \mathrm{~mm} \mathrm{TL}$, was generally observed during December-February, in shallow, nearshore waters. From the length composition of the two sexes of $P$. polyphagus, the total mortality coefficient $(Z)$, natural mortality coelficient (M), exploitation rate (U), and the $E_{\max }$ were estimated (Table 1). The $Z$ for the entire 5-year period for males was 1.9 which varied from 2.57 in 1998 to 1.57 in 2001 . For fermales, $Z$ was 1.63 which varied from 1.57 in 1998 to 2.01 in 2000 . With the 
mean seawater temperature at $28^{\circ} \mathrm{C}, \mathrm{M}$ for males and females were 0.53 and 0.60 , respectively. The relative yield per recruit (Y/R) analysis indicated that the yield can be maximised when the exploitation ratios are 0.46 and 0.53 for males and females, respectively. However, the present exploitation ratios are 0.65 for males and 0.63 for females, which are much higher. At such exploitation ratios the biomass is reduced to 0.30 , which may not sustain future stock.

\section{South-west coast fishery}

On the south-west coast, spiny lobster fishing began at subsistence level and gradually transformed into a commercially important fishery. Colachel and Muttom were the two important landing centres where traditional traps made of palmyrah frond were used. Fishers used to dive in the evening and place the baited traps near the mouth of large crevices. Traps were lifted the next morning. Later, gill-nets and trammel-nets were introduced and now traps are used at a few centres. Annual landings gradually decreased from a peak of $301 \mathrm{t}$ in 1966 to $7.6 \mathrm{t}$ in 1996 , with only $4 \mathrm{t}$ recorded in 2002 . About $92 \%$ of the catch comprised $P$. homarus, the remainder being $P$. ornatus and Panulirus versicolor. The fishery was seasonal, extending from October to May with maximum landing during November-January. The fishing season coincided with the peak breeding season and $40 \%$ of the females caught during this period were egg-bearing. The size of $P$. homarus in the catches ranged from $91 \mathrm{~mm}$ to $280 \mathrm{~mm}$ TL.

In 1999, fishers ventured into deeper waters (150 $400 \mathrm{~m}$ ) off Quilon ("Quilon Bank") along the southwest coast. The deep-sea lobster $P$. sewelli was landed by trawlers as a bycatch along with deep-sea shrimps. The average annual landing of the species from the Quilon Bank during 1999-2002 was $340 \mathrm{t}$. The fishery was seasonal, commencing by
September-October and extending until FebruaryMarch. The total landing of $P$. sew'elli during 1999 2000 was $574 \mathrm{t}$, with a peak monthly landing of $180 \mathrm{t}$ in December. The landing decreased to $297 \mathrm{t}$ and 236 $t$ during the years 2000-01 and 2001-02, respectively. Maximum monthly landing was recorded in December $(110 \mathrm{t})$ during 2000-01 and March (49 t) during 2001-02. The size (TL) of $P$. sewelli ranged from $76-80 \mathrm{~mm}$ to $186-190 \mathrm{~mm}$ in males and from 71-75 $\mathrm{mm}$ to 201-205 $\mathrm{mm}$ in females. Occurrence of smaller size classes during December-January indicated entry of young ones into the fishery during these months. Maximum numbers of immature lobsters were recorded in January. Sexes were more-or-less equally distributed, with females comprising $47 \%$ of the catch during 2000-01 and 56\% during 2001-02.

\section{South-east coast fishery}

The south-east coast lobster fishery region encompasses Kanyakumari in the south to Chennai in the north. Gill-net is the major gear operated in the southern region as against the trawl nets used widely in the northern region with $T$. orientalis dominating the trawl fishery. In the gill-net fishery at Kayalpattinam, lobster catches increased from $42.2 \mathrm{t}$ (with a catch rate of $6.5 \mathrm{~kg} / \mathrm{unit}$ ) in 1993, to the peak catch of $50.6 \mathrm{t}$ (with a catch rate of $5.5 \mathrm{~kg} / \mathrm{unit}$ ) in 1994 (Fig. 5). However, the fishery declined to $4.4 \mathrm{t}$ (with a catch rate of $1.1 \mathrm{~kg} / \mathrm{unit}$ ) in 2002 . A change in the relative abundance of $P$. ormatus and $P$. homarus was also observed. $P$. homarus formed $72.3 \%$ of the total catch during 1978-89 whereas $P$. ormatus dominated the fishery $(60.6 \%)$ during 1993-2002. The modal length of male $P$. homarus occurring in the fishery decreased from $245 \mathrm{~mm}$ TL during 1978 to $145 \mathrm{~mm}$ TL during 2002. The modal length of females also decreased from $195 \mathrm{~mm}$ TL to $165 \mathrm{~mm}$ TL during this period. Meanwhile, the modal length of both

Table 1 Stock parameters of males and females of Panulirus polyphagus in Mumbai, India. (Z, total mortality coefficient; F, Fishing mortality; E, exploitation ratio.)

\begin{tabular}{lllllll}
\hline Parameter & Sex & 1998 & 1999 & 2000 & 2001 & 2002 \\
\hline $\mathrm{Z}$ & Males & 2.57 & 1.96 & 2.01 & 1.57 & 2.71 \\
& Females & 1.57 & 1.87 & 2.04 & 1.66 & 1.76 \\
$\mathrm{~F}$ & Males & 2.02 & 1.43 & 1.48 & 1.04 & 2.18 \\
$\mathrm{E}$ & Females & 0.97 & 1.27 & 1.44 & 1.06 & 1.16 \\
& Males & 0.79 & 0.73 & 0.74 & 0.66 & 0.80 \\
& Females & 0.62 & 0.68 & 0.71 & 0.64 & 0.66
\end{tabular}




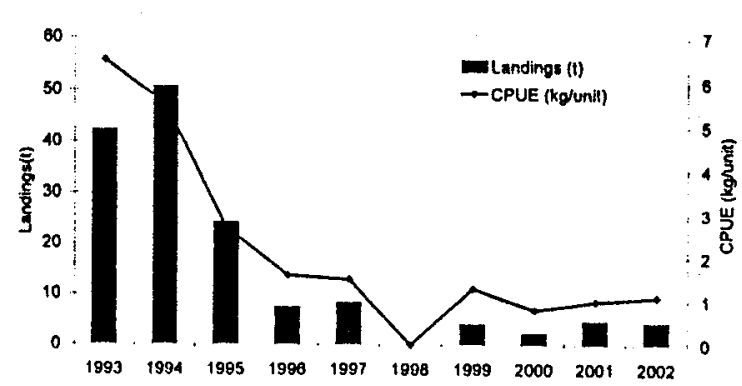

Fig. 5 Annual landing and catch per unit effort (CPUE) of spiny lobsters (Panulirus homarus and P. ornatus) in the gill-net fishery at Kayalpattinam, India.

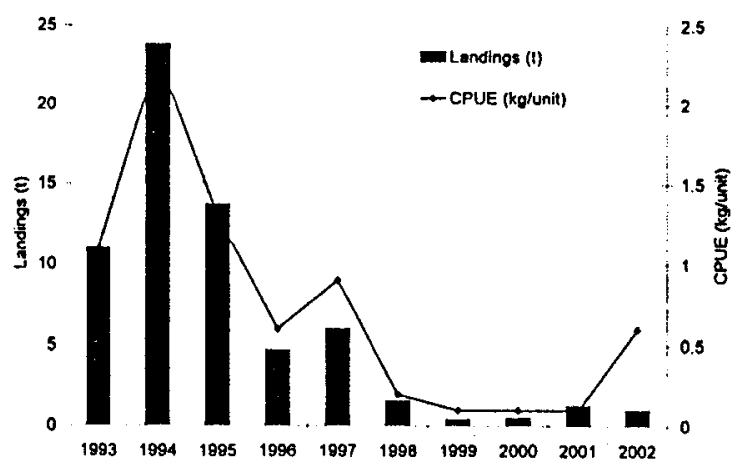

Fig. 6 Annual landing and catch per unit effort (CPUE) of spiny lobsters (Panulirus homarus and $P$. ornatus) in the gill-net fishery at Tharuvaikulam, India.

males and females of $P$. ornatus showed an increase from $175 \mathrm{~mm}$ to $195 \mathrm{~mm}$ TL. At Tharuvaikulam, another gill-net landing centre, the landings decreased gradually from $11 \mathrm{t}$ (with a catch rate of $1.1 \mathrm{~kg} /$ unit) in 1993 , to $1.1 \mathrm{t}$ (with a catch rate of $0.6 \mathrm{~kg} /$ unit) in 2002 (Fig. 6). Though lobsters were landed throughout the year, the peak seasons were October-December and April-May. During the entire period of study, ovigerous females of $P$. ornatus were not encountered in the inshore gill-net fishery. However, large males and berried females of $P$. ornatus were landed in small quantities at Nagapattinam by gill-nets operated in deeper waters.

In a previous study conducted at Kovalam, near Chennai, during 1986-88, the catch composition of lobsters from the gill-net fishery and trammel-net fishery was examined. The size of $P$. homarus in the trammel-net fishery ranged from $23 \mathrm{~mm}$ to $100 \mathrm{~mm}$ CL with nearly $35 \%$ in the range of $23-50 \mathrm{~mm} \mathrm{CL}$. In comparison, size of lobsters caught in gill-nets

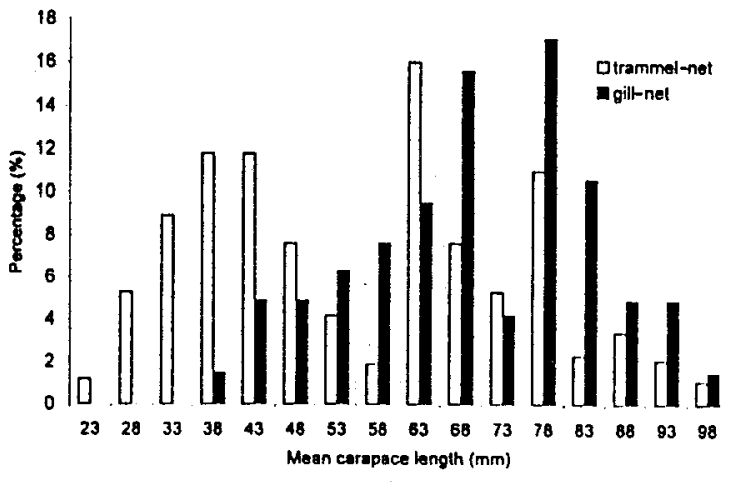

Fig. 7 Length-frequency distribution of Pamulirus homartus in the trammel-net and gill-net fishery at Kovalam, India.

ranged from $38 \mathrm{~mm}$ to $100 \mathrm{~mm} \mathrm{CL}$ with a majority in the range of $55-80 \mathrm{~mm} \mathrm{CL}$. Studies showed that $50 \%$ of $P$. homarus caught in trammel-nets were below $55 \mathrm{~mm} \mathrm{CL}$, the size at first maturity, whereas only $25 \%$ were below the size at first maturity in the gill-net catches (Fig. 7).

\section{Awareness programme for lobster conservation}

A project on community participation in lobster resource management was initiated in the fishing village of Kadiyapattinam (near Kanyakumari) (Fig. 1), in November 2002. It is increasingly understood that lobster management is not possible just through an isolated promulgation of a law. Involvement of fishers in the management of the resources, on which they depend for their livelihood, could be an alternative strategy. Five meetings, involving fishers, traders, exporters, and fisheries officials were held to discuss the need for development of strategies for sustainable exploitation of the lobster resources. Fisher meetings were organised at Kadiyapattinam near Kanyakumari, Veraval in Gujarat, and Mumbai in Maharashtra to convey the message of responsible fishing to the community. Lobster conservation leaflets, stickers, and wall posters were distributed in lobster fishing villages. Two hundred egg-bearing lobsters purchased from fishers were "V" marked on the uropods and released, to educate the fishers on the need for protection of lobsters carrying eggs. On two occasions, fishers released the marked lobsters voluntarily. They were shown the advantage of using wire traps with escape vents and are slowly being convinced that, in the long term, such responsible fishing methods will benefit them economically. Rallies were also held at three fishing villages in Gujarat to convey the message of conservation. 


\section{DISCUSSION}

Though not big in volume, lobster is an important crustacean resource from the Indian seas. Commercial exploitation of the lobster fishery in India began in the early 1950s. However, reliable data on the landings are available only from 1968 . The fishery experienced rapid growth in 10 years, landing $3000 \mathrm{t}$ in 1975 . Though the fishery suffered a setback for nearly 5 ycars afterwards, it atlained the peak landing of $4075 \mathrm{t}$ in 1985. The sharp fall in the landings in 2001 and 2002. however, was an indication of the growing instability of most of the lobster stocks on both the east and west coasts of India.

In the north-west, lobsters are incidentally caught in trawl nets, except for a small quantity landed by gill-nets at Veraval. In Mumbai, the slipper lobster $T$. orientalis disappeared from the fishery by 1994 (Deshmukh 2001). Heavy reduction in the biomass of the species from overexploitation resulted in the collapse of the fishery. Unlike most of the tropical species, $T$. orientalis showed a single well-defined breeding period from October to January. The sex ratio was disproportionate with females outnumbering males, particularly during the breeding period. It is also a slow-growing species with relatively low fecundity (Kabli \& Kagwade 1996a). Exploitation of the spawning females which formed $60 \%$ of the total landing might have been detrimental to the recruitment process, resulting in rapid decline of the fishery in the waters off Mumbai. This is a classic example of recruitment overfishing which is not precluded by the growth overfishing.

The ovigerous females of $P$. polyphagus occurred throughout the year, the month-wise abundance showing peaks in August-September. Thus, unlike $T$. orientalis, the species breeds throughout the year. However, Kagwade (1988a) reported two major spawning peaks, in January and September. In the present study, no such peak was observed in January. The size at $50 \%$ maturity of females is $205 \mathrm{~mm} \mathrm{TL}$ weighing $218 \mathrm{~g}$ (Kagwade 1988a), and the annual production of eggs is as high as 143000 and 4.72 million in specimens of $180 \mathrm{~mm}$ and $353 \mathrm{~mm} \mathrm{TL}$, respectively (Kagwade 1988b). With the assumption that natural mortality remained constant during the period, the maximum yield of. $P$. polyphagus could have been obtained at the exploitation ratio $\left(\mathrm{E}_{\text {max }}\right)$ of only 0.46 for males and 0.53 for females. However, it was as high as $0.66-0.80$ for males and $0.62-0.71$ for females. It is important to note that at such exploitation ratios, the biomass of the stock is reduced to less than $50 \%$, which clearly indicates overfishing of the stock. This situation, therefore, calls for immediate management action to save the stock from collapse. Action should be taken to conserve the spawning stock during SeptemberOctober and the juveniles during December-January when they abound in the shallow coastal waters.

In Kanyakumari district, on the south-west coast, the fishery for $P$. homaris flourished during 196473. Increase in effort, introduction of gill-nets for fishing, and exploitation of egg-bearing lobsters during the peak breeding season have been the major factors responsible for reduction in landings. George $(1965,1973)$ observed that the peak breeding season for $P$. homarus coincided with the active fishing season and suggested a minimum legal size of $130 \mathrm{~mm}$ or $140 \mathrm{~mm}$ TL for the species exploited from the south-west coast. $P$. homarus is an inshore species with restricted movements (Mohamed \& George 1968) and is therefore highly vulnerable to fishing. Trammel nets bring in large quantities of juveniles and subadults, which otherwise would sustain the fishery. Based on the current landing data and biological information on the mean size of $P$. homarus, it could be deduced that the stock has been overexploited. A similar situation prevails in the gillnet fishery at Kayalpattinam and Tharuvaikulam. Reduction in the landing and modal size of $P$. homarus is indicative of growth overfishing and requires immediate remedial measures to protect the juvenile population and breeding females. $P$. ormatus landed by gill-nets from the inshore fishing grounds along the south-east coast comprise juveniles and subadults. Adults are caught incidentally in trawl nets. Exploitation of the juvenile population from the inshore nursery areas may have an adverse impact on the fishery in the long term. Kagwade et al. (1991) did not notice a single berried specimen of the species either in the gill-net or in the trawl fishery. The possibility of $P$. ornatus migrating through the Palk Strait to a deeper breeding ground near the northern Sri Lankan coast cannot be ruled out. Similiar migratory behaviour of spawning females of $P$. ornatus through the Torres Strait in northern Australia has been reported (Skewes 1994). Migration to deeper areas keeps the breeding population away, probably giving a natural protection from large-scale exploitation. Fishers from Nagapattinam, who fish in decper waters, land adult lobsters and berried females from this ground, though in small quantities. Subramanian (2004) studied the fishery for $T$. orientalis in the trawl fishery along the Chennai const during 1982-99. The average annual catch of $10 \mathrm{t}$ during 1982-85 
increased to $60 \mathrm{t}(0.14 \mathrm{~kg} / \mathrm{h})$ in 1993 and $115 \mathrm{t}$ $(0.23 \mathrm{~kg} / \mathrm{h})$ in 1994 . However, a declining trend was recorded in the following years with only $8 \mathrm{t}$ $(0.01 \mathrm{~kg} / \mathrm{h})$ in 1999 . Maximum landing was in October. The mean sizes of $T$. orientalis landed were $153.6 \mathrm{~mm}$ and $156.9 \mathrm{~mm}$ TL for males and females respectively. The females attained maturity at $105.5 \mathrm{~mm}$ TL. Maximum spawning activity was observed during January-March and June-July with peak recruitment around October and January.

\section{Management}

Unlike many other countries, the trawl fishery for lobsters in India does not constitute an exclusively targeted fishery. Therefore, optimising the trawlers for lobsters alone is not an option. Neither is observing a closed season for $P$. polyphagus along the Maharashtra coast during the peak breeding season (September-October) as fishing by mechanised boats in the State is already banned during the monsoon (10 June-15 August). Therefore, one of the management options left is to return egg-bearing females back to sea, at least during August-October so that the spawning stock is protected. Recruitment of juvenile lobsters (40-160 g) generally takes place during December-February. These undersized lobsters do not fetch good prices and therefore could also be returned to sea. $P$. polyphagus is a hardy species which remains alive for 1-2 h after it is brought on board by trawl net. Hence, releasing back the undersized and berried lobsters would ensure future recruitment process. As $T$. orientalis occurs only in small numbers along the coast of Maharashtra, total conservation of the remaining residual population by relurning the lobsters caught and a legal ban on landing of the species are the only options which can be followed in future.

Table 2 Minimum legal size for export of lobsters from India (Notification No. 16 (RE 2003)/2002-07 dated 17 July 2003, Ministry of Commerce and Industry, Government of India).

\begin{tabular}{lccc} 
Species & $\begin{array}{c}\text { Live/chilled/ } \\
\text { frozen } \\
(\mathrm{g})\end{array}$ & $\begin{array}{c}\text { Whole } \\
\text { cooked } \\
(\mathrm{g})\end{array}$ & $\begin{array}{c}\text { Tail } \\
(\mathrm{g})\end{array}$ \\
\hline Panulirus polyphagus & 300 & 250 & 90 \\
P. homarus & 200 & 170 & 50 \\
P. ornatus & 500 & 425 & 150 \\
Thenus orientalis & 150 & - & 45 \\
\hline
\end{tabular}

The drastic decline of the fishery along the coast of Gujarat is also of serious concern and demands similar management measures. Intensive exploitation of juvenile $P$. polyphagus from the inshore reef area by gill-net at Veraval in Gujarat should be banned, if the fishery is to be sustained.

On the south-west coast, closure of the fishery for $P$. homarus during the peak breeding month of November may protect the spawning stock. A ban on operation of trammel-nets on the entire southwest and south-east coasts may prevent exploitation of juveniles which comprise nearly $35 \%$ of the catch. Although the spawning stock of $P$. ormatus in deeper waters may not be in danger of being overfished along the south-east coast, the gill-net fishery for juveniles may be detrimental to the stock, as indicated by the decline in the catch and catch rate during the last decade.

The spiny lobster fishery in India is an openaccess one and any restriction imposed is likely to be resisted by fishers. Co-operation among fishers, scientists, and government agencies is important for implementing sustainable management programmes. Apart from legal implementation of fishing regulations, education and creation of awareness among fishers on the negative impact of fishing and marketing egg-bearing lobsters and juveniles, may bring a subtle change in their mindset. The educational programme initiated in 2002 is making slow progress in inculcating a sense of responsible fishing and trade. However, fishers are realising that the lobster fishery on which they depend for their livelihood is gradually becoming depleted, and implementation of regulatory measures would benefit them in the long run. Village-level meetings. distribution of educative posters, stickers and pamphlets, video film shows, $\mathrm{V}$ notching and releasing of egg-bearing lobsters, and distribution of lobster traps as a less destructive fishing method, are some of the activities implemented under this programme. Enforcement of the minimum legal size, for export of four commercially important species of lobsters in the country (Table 2), is a positive step from the Ministry of Commerce and Industry, Government of India. Implementation of the minimum legal size for fishing, closure of spiny lobster fishery during the peak spawning season in the southern region, and a ban on trammel-nets are the regulatory measures recommended for implementation by the State Governments. As lobster fishing is a socio-economic activity involving fishers and traders, any regulatory measure implemented should also consider socioeconomic aspects. 


\section{ACKNOWLEDGMENTS}

We thank Dr Mohan Joseph Modayil, Director of the Central Marine Fisheries Research Institute, for the facilities provided and encouragement. We also gratefully acknowledge receipt of the data on total landing of lobsters by trawlers, from the Fishery Resources Assessment Division of the Institute. The first author thanks Marine Products Export Development Authority, India and Dr Stuart Frusher, Convenor of the 7th International Conference on Lobster Biology and Management, for providing the financial support to present the paper at the Conference. The support from Dr Josileen Jose, Ms Jeena, and Mrs K. V. Sajitha is also gratefully acknowledged.

\section{REFERENCES}

Balasubramanyam, R.; Satyanarayana, A. V. V.; Sadanandan, K. A. 1960: A preliminary account of the experimental rock-lobster fishing conducted along the south-west coast of India, with bottom set gill-nets. Indian Journal of Fisheries 7: 405-422.

Balasubramanyam, R.; Satyanarayana, A. V. V.; Sadanandan, K. A. 1961: A further account of the rock-lobster fishing experiments with the bottom-set gill-nets. Indian Journal of Fisheries 8: 269-290.

Chhapgar, B. F.; Deshmukh, S. K. 1971: Lobster fishery of Maharashtra. Journal of the Indian Fisheries Association /(I): 74-86.

Deshmukh, V. D. 2001: Collapse of sand lobster fishery in Bombay waters. Indian Journal of Fisheries 48(I): 71-76.

Gayanilo, F. C.; Sparre, P.; Pauly, D. 1996: The FAOICLARM Fish Stock assessment tools (FiSAT). FAO Computerized Infornation Series (Fisheries) No. 8. Rome, Italy, Food and Agriculture Organisation. 124 p. and 3 diskeltes.

George, M. J. 1965: Observations on the biology and fishery of the spiny lobster Panulirus homarus (Linnaeus). Proceedings Symposium on Crustacea, Part IV. Marine Biological Association of India, Cochin. Pp. 1308-1316.

George, M. J. 1973: The lobster fishery resources of India. In: Proceedings Symposium on the living resources of the seas around India, Cochin, December 1968. Special Publication, Central Marine Fisheries Research Institute. Pp. 570-580.

John, C. C.; Kurian, C. V. 1959: A preliminary note on the occurrence of deep-water prawn and spiny lobster off the Kerala Coast. Bulletin Central Research Institute, Trivandrum, Ser. C. 7(1): 155-162.

Kabli, L. M.; Kagwade, P. V. 1996a: Reproductive biology of the sand lobster Thenus orienralis (Lund) from Bombay waters. Indian. Journal of Fisheries 43(l): 13-25.
Kabli, L. M.; Kagwade, P. V. 1996b: Age and growth of the sand lobster Thents orientalis (Lund) from Bombay waters. Indian Joumal of Fisheries 43(3): 241-247.

Kabli, L. M.; Kagwade, P. V. 1996c: Morphometry and conversion factors in the sand lobster Themus orientalis (Lund) from Bombay waters. Indian Journal of Fisheries 43(3): 249-254.

Kagwade, P. V. 1987a: Morphological relationships and conversion factors in spiny lobster Pamulirus polyphagus (Herbst), Indian Journal of Fisheries 34(3): 348-352.

Kagwade, P. V. 1987b: Age and growth of the spiny lobster Pamulirus polyphagus (Herbst). Indian Jounal of Fisheries 34(4): 389-398.

Kagwade, P. V. 1988a: Reproduction in the spiny lobster Panulirus polyphagus (Herbst). Journal of $\mathrm{Ma}$ rine Biological Association of India $30(/ \& 2)$ : $37-46$.

Kagwade, P. V. 1988b: Fecundity in the spiny lobster Panulirus polyphagus (Herbst). Journal of Ma. rine Biological Association of India 30(1\&2): 114-120.

Kagwade, P. V.; Manickaraja, M.; Deshmukh, V. D.; Rajamani, M.; Radhakrishnan, E. V.; Suresh, V.; Kathirvel, M.; Rao, G. S. 1991: Magnitude of lobster resources of India. Journal of Marine Biological Association of India 33(l\&2): 150-158.

Kurian, C. V. 1964: Deepwater prawns and lobsters off the Kerala coast. Fishery Technology: symposium on prawn fisheries in India, Cochin, October 3-4, 1964. Pp. 51-53.

Miyamoto, H.; Shariff, A. T. 1961: Lobster fishery off the south-west coast of India-anchor hook and trap fisheries. Indian Joumal of Fishcrics \&: 252-268.

Mohamed, K. H.; George, M. J. 1968: Results of the tagging experiments on the Indian spiny lobster, Panulirus homarus (Linnaeus)-movement and growth. Indian Journal of Fisheries 15: 15-26.

Nair, R. V.; Soundararajan, R.; Dorairaj, K. 1973: On the occurrence of Panulirus longipes longipes, Panulirus penicillatus and $P$ anulirus polyphagus in the Gulf of Mannar with notes on the lobster fishery around Mandapam. Indian Journal of Fisheries 20(2): $333-350$.

Pauly, D. 1980: On the interrelationships between natural mortality, growth parameters and mean environmental temperature in 175 fish stocks. Iournal du Conseil international pour I' Exploration de la Mar 39(2): 175-192.

Pauly, D. 1984: Length converted catch curve. A powerful tool for fisheries research in the tropics. ICLARM Fishbyte 2(3): 9-10. 
Radhakrishnan, E. V. 1995: Lobster fisheries of India. The Lobster Newsletter 8(2): 1, 12-13.

Radhakrishnan, E. V.; Manisseri, M. K. 2003: Lobsters In: Mohan Joseph, M.; Jayaprakash, A. A. ed. Status of exploited marine fishery resources of India. Central Marine Fisheries Research Institute, Kochi-682014, India. Pp.195-202.

Rajamani, M.; Manickaraja, M. 1991: On the collection of spiny lobsters by skin divers in the Gulf of Mannar off Tuticorin. Marine Fisheries Information Service, Technical \& Extension Series No. 113: 17-18.

Rajamani, M.; Manickaraja, M. 1995: Fishery of the painted cray fish Panulirus versicolor in the Gulf of Mannar. Marine Fisheries Information Scruice, Technical \& Extension Series No. 140: 6-7.

Rajamani, M.; Manickaraja, M. 1997a: On the fishery of the spiny lobster off Tharuvaikulam, Gulf of Mannar. Marine Fisheries Information Service, Technical \& Extension Series No. 146: 7-8.

Rajamani, M.; Manickaraja, M. 1997b: The spiny lobster resources in the trawling grounds off Tuticorin. Marine Fisheries Information Service, Technical \& Extension Series No. 148: 7-9.

Silas, E. G. 1969: New findings on trawling grounds on the continental slope bordering the Wadge Bank and extending to the Gulf of Mannar. Brilletin, Central Marine Fisheries Research Institute No. 12: 34-37.

Skewes, T. D. 1994: Changes in the composition and moult frequency of the ornate rock lobster Panulirus ornatus population in Torres Strait associated with an annual breeding migration. Bulletin Marine Science 54(l): 38-48.

Subramanian, V. T. 2004: Fishery of sand lobster Themus orientalis (Lund) along Chennai coast. Indiam Journal of Fisheries $5 /(I): 111-115$. 